Sonja M. Mork has for several years worked as a secondary school science teacher, but is now a doctoral student at the Viten project and situated at the Department for Teacher Education and School Development at the University of Oslo. She is writing a thesis on the use of the digital teaching resources at the web-site www.viten.no. Mork also works as a program developer in the project "ABM - school and web", directed by Norwegian Archive, Library and Museum Authority (ABM). In this project a digital teaching program connecting schools and the activities of $A B M$ is developed.

\title{
Argumentation in science lessons: Focusing on the teacher's role
}

\author{
Abstract \\ This paper reports data from a case study of role-play debates on the controversial issue of wolves in \\ Norway. The participants are 23 students at the age of 14-15 and their teacher. Transcripts from the \\ role-play debates are the data sources. The focus of the paper is the teacher role regarding manage- \\ ment and teacher interventions in activities involving argumentation. A typology of teacher inter- \\ ventions and reasons for these is developed, that might serve as a useful tool for student teachers and \\ teachers not experienced in managing debates and discussions.
}

\section{INTRODUCTION}

Although argumentation is an important activity in science, and an important curriculum goal in science education, activities promoting arguments are not common in science lessons. There are a number of possible reasons for this, although one obvious factor is the role of the teacher. The contributions of this paper is the identification of some potential difficulties regarding management of activities involving argumentation in science, and some of the solutions, through a small scale case study, and hence explore possible reasons why argumentation is not more prominent in science education.

The context of the teaching sequence is role-play debates about the controversial issue of wolves in Norway. A web-based teaching program ${ }^{1}$ about wolves developed by the Viten project (Mork \& Jorde, 2004) was used, in which students worked on information and various types of tasks ending with a role-play debate. The Viten wolf program is designed to accomplish the following goals: First students should learn about fundamental ecological ideas like population dynamics, predator-prey relations and ecological management. Secondly students should learn about different viewpoints and possible solutions to the conflict. Finally students should practice argumentation i.e. participate in an actual debate where they can draw upon knowledge gained from the Viten wolf program to make, support and justify arguments and claims. The teaching sequence is in line with Sadler's (2004) suggestion that students would benefit, in particular, from instruction related to dealing with contradictory evidence, the formation of counterarguments, and the importance of providing justifications for claims.

\footnotetext{
${ }^{1}$ http://viten.no
} 


\section{BACKGROUND}

\section{Argumentation is important in science education}

Controversy and argumentation are regarded as important aspects of the nature of science (Latour \& Woolgar, 1986). Deanna Kuhn (1993) suggests that scientific activity can be characterized in broad terms as exploration and argument, where argument is a supplement to science as exploration. She further argues that not just the theories but even the so-called "facts" of science become argumentative constructions that must be entered into the arena of public debate. The science education community seems to agree that activities involving discourse and argumentation have a potential to enhance learning and hence should have a central place in school science (Driver, Leach, Millar, \& Scott, 1996; Duschl \& Osborne, 2002; Zohar \& Nemet, 2002; Sadler, 2004). This is also reflected in policy documents like Beyond 2000 (Millar \& Osborne, 1998), stating that the reason for situating argumentation as a central element in the learning of sciences has several functions in terms of e.g. generating the kind of knowledge and understanding essential to scientific literacy and improving student engagement and interest in science.

According to Costello and Mitchell (1995) argument can be understood as a means to put forward a position in preference to others and as a means to discover, a perhaps shared, perspective, i.e. argument to win, and argument to arrive at a decision. They further state that argument can be understood in terms of competition and consensus. Argument is a social operation, which is oriented to context and to purpose; it initiates change, it transforms the significance of material, it enables reflection and action, it brings divergent voices together in interaction, it signals belonging within a certain community, it seeks to persuade, to publicize, and to win (ibid).

Research has been conducted regarding argumentation as means of: improving the understanding of concepts, promoting a better grasp of epistemology in science, developing investigative skills and improving the quality of decision-making on socio-scientific issues (Solomon, 1992; Ratcliffe, 1996; Driver, Newton, \& Osborne, 2000; Kolstø, 2001; Simonneaux, 2001; Zohar \& Nemet, 2002; Mork \& Jorde, 2003). However, these studies seem to report on exceptions rather than common practice in science classrooms. As explored below, there seem to be considerable barriers for science teachers to implement such activities in their science classes.

\section{Activities promoting argumentation are not common in science teaching}

Solomon (1991) claims that science teaching has failed to empower students with the ability to argue scientifically through the kinds of socio-scientific issues that they are increasingly having to face in their everyday lives. So what do we know about the characteristic features of communication in science lessons today? Mortimer and Scott (2003) have developed a theoretical framework for categorising the communicative approach in classroom discourse. The framework is characterising the talk between teacher and students along each of two dimensions, dialogic-authoritative focusing on the diversity of points of view that are taken into account in the classroom discourse and interactive-non interactive focusing on the degree of interaction between classroom participants. Along these dimensions four classes of communicative approach are defined by:

- Interactive/dialogic: the teacher and students explore ideas, generating new meanings, posing genuine questions and offering, listening to and working on different points of view.

- Non-interactive/dialogic: the teacher considers various points of view, setting out, exploring and working on the different perspectives.

- Interactive/authoritative: the teacher leads students through a sequence of questions and answers with the aim of reaching one specific point of view.

- Non-interactive/authoritative: the teacher presents one specific point of view.

Each class of communicative approach serves a different educational purpose. However, there is some evidence that most science classrooms seem to be dominated by interactive/authoritative 
talk: Newton, Driver and Osborne (1999) report that secondary science classrooms are strongly teacher directed and few opportunities are given for students to contribute to the process of constructing knowledge in lessons, and the utilization of small groups, or whole class discussions appears to be very infrequent. An evaluation of the current Norwegian national curriculum for grade 1-10 describes the teaching in all non-practical subjects as generally dominated by teacher control, i.e. instructions and question-answer sequences (Haug, 2003). Similar patterns are found in an evaluation of work forms in upper secondary school physics in Denmark: Teacher lecturing was to a certain extent related to students' active participation in classroom conversations. However, these had features of examinations (Norrild, Angell, Bang, Larsen, Paulsen et al., 2001).

\section{Why are activities involving argumentation not more frequently used?}

There could be a number of reasons that science teachers hesitate to engage students in activities that support discourse and argumentation. In a review of informal reasoning regarding socioscientific issues Sadler (2004) conclude that the promotion of argumentation skills appear to be a difficult educational goal. Driver et al. (2000) have emphasised that science teachers have a limited pedagogical repertoire for dealing with argumentation and classroom discussions. Similarly, James T. Dillon (1994) lists some reasons that discourages teachers from discussions: Discussion skills are difficult and need to be learnt, both by students and the teacher. Discussions are also time-consuming, unpredictable in process and uncertain of outcome as much as unsure of success.

Duschl and Osborne (2002) suggest that before one can expect teachers to engage their students in argumentation, they need guidance in how to approach such issues. Research on teaching strategies for how to deal with activities involving argumentation is therefore needed to meet science teachers' lack of confidence and expertise in this area. Several authors suggest that if young people are to develop the skills of scientific argument, they must be offered opportunities to practice such reasoning, i.e. to articulate reasons for supporting a particular claim; to attempt to persuade or convince their peers; to ask questions; to relate alternate views; and to point out what is not known (e.g. Driver et al., 2000; Sadler, 2004). For such purposes Mortimer and Scott's (2003) notion of interactive/dialogic talk seems to be an appropriate vehicle. This type of communicative approach expects teachers to listen to, and take account of, students' utterances, and giving a type of response that continues the flow of discourse without necessarily evaluating each student's utterance. In contrast to interactive/authoritative talk, the teacher is not having complete control over where the discourse is heading. An interactive/dialogic approach is also in line with Ratcliffe's (1997) suggestion that class discussions are an effective way of encouraging students to explore controversial issues and of avoiding an authoritarian approach. This study reports from classroom debates with an interactive/dialogic communicative approach, focusing on the teacher role regarding management and teacher interventions.

\section{Research questions}

-What are the reasons for teacher interventions in managing the debates?

-What types of interventions are used by the teacher to manage the debates?

\section{DESIGN AND METHODOLOGY}

\section{Sample}

The participants were 23 Norwegian students at the age of 14-15. The teacher is the author of this paper, working as a secondary school science teacher when the teaching took place and not aware of the later approach to the data as a researcher. During a teaching period of two weeks, students spent four lessons working through the online information base and two lessons preparing and performing the offline role-play debates. Debates were video recorded and transcribed. 


\section{Role-play debate}

The closing activity, where students are able to use information collected and processed through working on an issue, is one of the most important parts of any teaching sequence. One main teaching purpose of the wolf program is to let students participate in an actual debate. The students were expected to identify information which supports a point of view and defend this view in a debate context where the rules were established and explained.

It was decided to conduct the debates as role-plays of TV debates between politicians, i.e. where a general issue and several sub-issues were on the agenda, a context familiar to most students. This design was chosen since the medium of TV debates is a good way of focusing on the nature of discussions and promotes an argumentative mode of discourse where students construct and defend arguments and refute other people's arguments, independent of their own opinion on the issue. Role-playing the various stakeholders in a conflict might help students understand that there is more than one legitimate perspective on a controversy, and that an individual's perspective is influenced by individual interests.

Three debates were conducted during one class period; each lasted about 10-15 minutes and was organised as a panel with two opposing groups, each consisting of 3-4 students. Students were assigned roles for or against wolves and the teacher acted as a moderator while students not in the panel had roles as active audience participants who could ask questions and challenge the panel. Former experiences in a class with non-active audiences showed that in the audience students were eager to participate and almost couldn't wait until it was their turn to sit in the panel. Similar experiences are confirmed by Simmoneaux (2001), who reported that the observers felt frustrated at not being able to take part. By involving the audience students were given several chances to engage.

\section{The teacher's role - a double role}

The teacher played a double role in being the moderator of the TV-debate, but she was also still the teacher. She defined the general content frame and through various interventions she had opportunity to influence and shape the debate according to the aims of the curriculum.

The role put some constraints on the teacher e.g. she was not supposed to explain things as in a more traditional teaching sequence. On the other hand the role allowed for strategies like challenging participants in the panel and to keep the debates going by turning statements into questions.

\section{Management and teacher interventions}

In managing most classroom situations the teacher must make interventions to maintain the flow of discourse. Here the teacher interventions are related to the curricular goals. In teaching that aims to introduce the students to some of the norms and practicalities of debates, it is important that the teacher models how to behave in a debate setting. Another critical task is to challenge the correctness of information introduced by the students. If this is not done, there is a danger that misunderstandings might be established.

Different kinds of classroom situations result in different kinds of teacher interventions. Several authors suggest that lack of procedures for running classroom discussions might be a main reason why science teachers hesitate to use activities involving argumentation (e.g. Dillon, 1994; Driver et al., 2000). As a response to this line of argument, the present study is developing a typology of teacher interventions and reasons causing them. The purpose of this is to offer teachers a tool that might guide them in developing strategies to handle argumentative discourse.

The data sources in this study are the transcripts of the debates. Data analysis was done through several stages: Firstly all teacher interventions and issues requiring action from the teacher were identified. Secondly these were classified according to the context in which they appeared. From 
this, the typology of teacher interventions and reasons for these was developed. The last stage of the data analysis was the inter-rater reliability test. The procedures for identifying teacher interventions and reasons were explained to a fellow researcher, who then used the typology as described in Table 1 to independently code all transcripts. Inter-rater reliability showed an initial agreement on $81 \%$. After a discussion between the coders, the agreement increased to $94 \%$.

\section{RESULTS}

A typology of teacher interventions and reasons is developed. Six main reasons prompting teacher interventions are identified. These are related to: Accuracy of content, narrow range of topic, debate off track, coming to a stop, level of participation and maintain order of speakers. Each reason prompts some sort of action from the teacher and these actions are characterised as: Challenge the correctness of content, extending the range of topic, get the debate back on track, keep the debate

Table 1: Overview of reasons for teacher interventions, teacher interventions and strategies identified in the debates. The third column shows the curriculum goals related to the teacher interventions.

\begin{tabular}{|c|c|c|}
\hline $\begin{array}{l}\text { Reasons for teacher } \\
\text { interventions }\end{array}$ & $\begin{array}{l}\text { Teacher interventions and } \\
\text { strategies }\end{array}$ & Curriculum goals \\
\hline $\begin{array}{l}\text { Accuracy of content: } \\
\text { - Wrong use of concepts } \\
\text { Wrong combination of } \\
\text { information }\end{array}$ & $\begin{array}{l}\text { Challenge the correctness: } \\
\text { - Rephrase and address } \\
\text { question to other group } \\
\text { - Ask for elaboration }\end{array}$ & $\begin{array}{l}\text { - } \quad \text { Learn about fundamental } \\
\text { ecological ideas } \\
\text { - } \quad \text { Learn about different } \\
\text { viewpoints and possible } \\
\text { solutions of the conflict }\end{array}$ \\
\hline $\begin{array}{l}\text { Narrow range of topic } \\
\text { - Too few sub-topics } \\
\text { covered } \\
\text { - Incomplete information }\end{array}$ & $\begin{array}{l}\text { Extending range of topic: } \\
\text { - } \quad \text { Pursuing particular parts } \\
\text { - } \quad \text { As students utterances } \\
\text { - } \quad \text { Reintroducing or } \\
\quad \text { introducing sub topics }\end{array}$ & $\begin{array}{l}\text { - } \quad \text { eearn about fundamental } \\
\text { ecological ideas } \\
\text { - Learn about different } \\
\text { viewpoints and possible } \\
\text { solutions of the conflict }\end{array}$ \\
\hline $\begin{array}{l}\text { Debate off track: } \\
\text { - Debate is on the edge of } \\
\text { the original theme }\end{array}$ & $\begin{array}{l}\text { Get debate back on track: } \\
\text { - Interrupt and switch focus }\end{array}$ & $\begin{array}{l}\text { - } \quad \text { Learn about fundamental } \\
\text { ecological ideas } \\
\text { - } \quad \text { Learn about different } \\
\text { viewpoints and possible } \\
\text { solutions of the conflict }\end{array}$ \\
\hline $\begin{array}{l}\text { Coming to a stop: } \\
\text { - } \quad \text { Authoritative student } \\
\text { statement } \\
\text { - } \quad \text { Student avoids questions } \\
\text { - } \quad \text { No answer/comment }\end{array}$ & $\begin{array}{l}\text { Keep the debate alive: } \\
\text { - } \quad \text { Rephrase content and } \\
\text { turn it into a question } \\
\text { - } \quad \text { Switch focus, challenge } \\
\text { - } \quad \text { Ask for elaboration, } \\
\quad \text { rephrase question }\end{array}$ & $\begin{array}{l}\text { Practice argumentation } \\
\text { skills } \\
\text { - Learn about fundamental } \\
\text { ecological ideas } \\
\text { - Learn about different } \\
\text { viewpoints and possible } \\
\text { solutions of the conflict }\end{array}$ \\
\hline $\begin{array}{l}\text { Level of participation: } \\
\text { - Too few students are } \\
\text { involved }\end{array}$ & $\begin{array}{l}\text { Involve more students: } \\
\text { - } \quad \text { Address question to } \\
\text { individual or group }\end{array}$ & $\begin{array}{l}\text { - Practice argumentation } \\
\text { skills }\end{array}$ \\
\hline $\begin{array}{l}\text { Maintain order of speakers: } \\
\text { - Train students in how to } \\
\text { behave in debates }\end{array}$ & $\begin{array}{l}\text { Focus on debate } \\
\text { technique: } \\
\text { - Give students permission } \\
\text { to speak on turn }\end{array}$ & $\begin{array}{ll}\text { - } & \text { Practice argumentation } \\
\text { skills }\end{array}$ \\
\hline
\end{tabular}


alive, involve more students and focus on debate technique. Within each action involves one or more strategies that the teacher uses to achieve the same action. It might for instance be that they pursue parts of students' utterances, ask for elaboration or address a question to an individual or group. These interactions are then related to the two broad areas of curriculum goals for the unit as a whole: Learn about subject content and practice argumentation skills. The characteristics of reasons for interventions, teacher interventions and strategies for implementing them are described further in Table 1.

The following section presents examples referring to reasons for interventions, interventions used and the strategies, and also how many occasions these appeared.

\section{Accuracy of content}

Six instances of teacher interventions related to accuracy of content were identified in the debates, relating to wrong use of concepts and wrong combination of information from different sources. If wrong information remains unchallenged it is likely that students believe this information is correct.

\section{a. Wrong use of concepts}

Sometimes the students use concepts wrongly, and the teacher needs to find out whether this is due to a misunderstanding of the concept.

\section{Example 1:}

1. Student $\mathbf{N 4}^{2}$ : "Between 1000 and 500, because we must have about 500 animals to get a viable pack in a way..."

2. Teacher: "What do you actually mean by viable pack?"

3. Student N4: "Yes, not pack, but in a way the whole..."

4. Teacher: "Stock?"

5. Student N4: "Yes"

6. Teacher: "What does viable stock mean then?"

Here the student uses the concept "viable pack". To the teacher it is obvious that he means population, since he is talking about that many individuals, but the teacher asks for elaboration (utterance 2) in order to explore whether the student has misunderstood the concept of population, or just forgotten the word. Since the rest of the class is audience it is important to express the right explanation of population. The student responds in utterance 3 but is not confident about the name of the concept and the teacher offers a suggestion before continuing asking for elaboration on viability in utterance 6 .

\section{b. Wrong combination of information from different sources}

In example 2, the student demonstrates general and correct knowledge about the relationship between predators and prey:

\section{Example 2:}

1. Student F2 ${ }^{3}$..."Besides, we in the Norwegian Hunting and Fishing Association have noticed a considerable decrease in the moose population, parallel with the increase in the wolf population. Moose that we could have hunted and sold. Reduction in the moose population means higher prices, and nobody wants that. This is threatening to our business."

\footnotetext{
${ }^{2} \mathrm{~N}$-students represent Nature protection organizations.

${ }^{3}$ F-students represent Farmer and Hunter organizations.
} 
2. Teacher: "But don't you in the Association for Nature protection have any understanding for these hunters that really have problems? Are there fewer moose to hunt, and do wolves kill their dogs?"

3. Student N1: "In the first place, the wolf population is still at a very low level, so I can't see that you could have noticed any reduction in the moose population. The wolf population is still too small."

However the student doesn't take into account the wolf population size in Norway: about 20-30 individuals. It is impossible for such a small population to have noticeable impact on the large moose population; by comparison, 38000 moose are shot by hunters every year. It is therefore important that the teacher challenges this information (utterance 2), and as we see, another student is correcting it in utterance 3 .

\section{Narrow range of topic}

In order to extend the range of the topic according to the curricular goals, the teacher asked questions to pursue particular parts of student utterances, to reintroduce or introduce certain aspects of the controversy. 27 teacher interventions were related to extending the range of the topic.

\section{a. Introduce new information}

As part of extending the range of the topic, the teacher on a few occasions introduced a new piece of information to the students:

\section{Example 3:}

1. Student F2: "500-1000, that's an unacceptable number of wolves. We think that we should have as few as possible. And they should be isolated from areas that are needed by people."

2. Teacher: "How are you going to do that then? Wolves are animals that wander over large areas. How is one supposed to isolate them?"

3. Student F1: "Place them on an island."

4. Student F2: "We in the Norwegian Hunter and Fisher Association have worked out a plan for this."

5. Teacher: "Maybe you could tell us a bit about that plan?"

6. Student F3: "Yes, we are going to take most of the packs of wolves present in Norway, and place them in one area. A quite large bounded are in a wood in the eastern part of Norway. And there we are going to try to keep them in, in a way. So that in this area we are going to have as few individuals as possible of livestock and other animals the wolves could take. But of course, we must have some moose and sheep and so on, because the wolves have to learn to eat by themselves too.

7. Teacher (to $\mathrm{N}$-group): "Do you believe that it will be possible to limit the wolves to a restricted area?"

8. Student N1: "No, absolutely not! The thing is that wolves wander a lot. They are not at rest, and you can't decide that the wolves are going to stay in one area. For example, it is almost the same with bears. They also wander. There was a killer bear here that was moved to Finland, from Norway. But after a year or something, then it was back again, so you can't do that."

In utterance 2, the teacher is introducing the fact that wolves are wandering over large areas, information central to the question of population size and thereby also the controversy. However, this piece of information is not picked up by a student until utterance 8 . Utterance 5 is another example related to extending the range of the topic when the teacher asks for elaboration. 


\section{b. Pursue particular parts of students' utterances/ask for elaboration}

Students often take for granted that other students have the same knowledge as themselves. A part of the teacher role is to encourage students to share this piece of information with the rest of the class as shown in example 4, where the teacher asks for elaboration:

\section{Example 4:}

1. Student N4: "It is possible to find an arrangement where there are wolf zones that are more limited."

2. Teacher: "What do you mean by wolf zones? It might be someone that doesn't know."

3. Student N4: "Wolf zones are zones where wolves live without many people, so that they doesn't create problems."

\section{Debate off track}

During classroom debates it is not unusual that students get carried away and move away from the original theme. The teacher therefore has an important role in preventing this from happening. This is a challenge because at the same time the teacher doesn't want to intervene too much in the debates. Two teacher interventions were related to debate off track. In example 5, utterance 1 is a typical example of a comment on the edge of the chosen theme. Another student tries to keep to the original theme in utterance 2 , but it is difficult. The teacher therefore intervenes by interrupting the discourse and switching the focus to population size by challenging one particular group.

\section{Example 5:}

1. Student N3: "Yes you are saying that the wolves move. Aren't we moving also? We move just as much as the wolves..."

2. Student F1: "Yes, of course, but there are certain differences between humans and wolves really."

3. Teacher: "To interrupt you a bit here, how many wolves do you mean that we should have in Norway? How many wolves do you (F-group) mean that we should have? Realistically?"

\section{Coming to a stop}

There can be a number of reasons that debates come to a stop. I define coming to a stop as incidents occurring when there is a break in the discourse due to authoritative statements from students, students avoiding answering questions or due to no student response to questions or comments. In the present study such incidents occurred eight times.

\section{a. Authoritative statement from a student}

\section{Example 6:}

1. Teacher: "But isn't it a pity, because the wolves are important parts of the ecosystem too, aren't they?"

2. Student F2: "No, absolutely no!"”

3. Teacher (to $\mathbf{N}$-group): "Have you anything to say to that? ... Which function do wolves have exactly? Why do you want to protect them?"

4. Student F1: "Yes, why should we have wolves?"

5. Student N3: "They are a part of Norway though..."

6. Student N1: "The wolf is an endangered species, and we would like to protect the species we have in Norway."

7. Student N2: "The wolves are in danger of going extinct, and the sheep are not." 
In utterance 2, a student responds by a very authoritative claim that makes it difficult for other students to continue. The teacher handles the situation by reshaping the question and adds another question addressed to the other group. As we can see, student F1 manages to insert a quick provoking question in utterance 4 before students in the $\mathrm{N}$-group respond to the teacher and continue the flow of discourse in a cumulative manner by repeating, confirming and elaborating (Mork, in prep.).

\section{b. Student avoids question}

\section{Example 7:}

1. Teacher: "But you said that the wolves were not dangerous, is that right? Are wolves dangerous? Do they kill humans?"

2. Student F2: "Humans are not the Norwegian Hunter and Fishing Association's biggest concern..."

3. Teacher: "But do wolves kill humans? Can we get that sorted out?"

4. Student N1: "It is more than 200 years since wolves killed a human. If you drive your car into a moose you could die from that too."

Student F2 avoids answering the question from the teacher in utterance 2, and no other students are responding. In utterance 3 the teacher repeats her prior question, but this time in a more challenging way, resulting in a response in utterance 4.

\section{c. No answer or comment from students}

\section{Example 8:}

1. Teacher: "Do you have any comments to that (F-group)?"

2. Nobody answers...

3. Teacher: "But do you (N-group) understand that it is a problem for them that the wolves are eating their livestock? It must be horrible to find their livestock eaten by wolves?"

4. Student N3: "We do have examples that Polish shepherd dogs have been used to watch sheep."

Here, nobody responds to a question from the teacher, hence she rephrases what has been said earlier and addresses the question to one group in a challenging language to provoke the students. The debate continues with student N3 suggesting an alternative to free range farming.

\section{Level of participation}

Sometimes just a few students are involved in the discourse. Addressing questions to individuals or groups is an efficient and commonly used strategy to involve more students. Students feel more obliged to answer and participate in such situations. Here, the teacher uses this strategy if one group or the audience has dominated the discourse i.e. had three or more utterances in a row. Five such episodes were identified.

\section{Example 9:}

1. Teacher (To N-group): "Doesn't that sound terrible? It must be terrible to find their livestock that they have a relationship to, killed by wolves?"

2. Student N4: "You don't have a relationship to your animals if you release them out in the woods and just let them go there on their own. Either you must look after you livestock, or you must find something else to do!"

3. Teacher: "Comment from student N1."

4. Student N1: "Yes, when you let your livestock out in the nature there will certainly be predators there, and you must take the consequences of that!" 
5. Teacher: "Student N3?"

6. Student N3: "Yes, I was going to say the same thing."

7. Teacher (To F-group): "Yes, what do you say about this?"

Example 9 shows two teacher interventions dealing with the level of participation. In utterance 1 the teacher aims to switch the focus to the $\mathrm{N}$-group after a sequence of four utterances from the F-group. The N-group responds in utterance 2, 4 and 6 before the teacher is involving the F-group again in utterance 7 .

\section{Maintain order of speakers}

36 teacher interventions in the debates were just management i.e. giving students permission to speak on their turn, as a part of learning how to behave in a debate context.

\section{Discussion}

The main purpose of this study was to investigate classroom debates and identify some potential difficulties and possible solutions by focusing on the teacher role. A typology of six main reasons for teacher interventions and corresponding interventions is developed. All identified teacher interventions and reasons causing them are of a general character and the typology therefore has a potential to serve as a guiding tool for teachers in managing other debates regardless of issue.

The importance of using activities involving argumentation in science lessons has been emphasized by many scholars (e.g. Millar \& Osborne, 1998; Sadler, 2004). However, such activities are still rarely used by science teachers. This is most commonly explained by teachers' lack of strategies for handling classroom discussions and that such activities are both time consuming and unpredictable.

Like many science teachers and students, the participants in this study were not particularly familiar with activities involving argumentation. The teacher therefore took an active role as the manager of the debates. The driving force of her management was the three curriculum goals: Students should learn about some fundamental ecological ideas, different viewpoints in the wolf conflict and they should practice argumentation skills. These goals are in line with Dillon's (1994) suggestion that helping the class to learn how to discuss is a part of helping the class to discuss the topic in question.

There are various interventions teachers can use when dealing with activities involving argumentation. The typology developed here describes six types of teacher interventions: Challenge the correctness of information, extending the range of the topic, get the debate back on track, keep the debate alive, involve more students and focus on debate techniques. Each intervention is made concrete by corresponding strategies like asking for elaboration, rephrasing, address questions to specific students or give students permission to speak. The provided examples show how the teacher through these strategies influenced the content and the flow of discourse in the debates. For instance, students elaborated more on content and focused the discourse according to the original theme.

In classroom debates or discussions the teacher has to act from second to second. With the benefit of hindsight, there are also things that could have been handled differently in the present debates, for instance regarding the notion of wait time (e.g. Wellington \& Osborne, 2001). In cases where the debates came to a stop or in situations related to narrowing the range of the topic, the teacher might have waited longer before intervening. Another example is five occasions were the teacher asks two questions almost simultaneously. The second question might include a new concept or information that changes the focus away from the initial one. In doing so, the teacher might confuse the students, or give them a chance to choose which line of information to pursue. If the teacher was conscious about these things before the debate, she could have acted differently in those situations. 
The strategies used by the teacher in the presented debates are well known and probably part of most teachers' repertoire of teaching strategies. This suggests that lack of strategies for handling classroom debates (e.g. Dillon, 1994; Driver et al., 2000) need not be a reason why science teachers hesitate to run such activities. For student teachers and teachers inexperienced in handling argumentative discourse, it will be useful to get an idea about situations they might have to respond to in practicing such activities. The typology developed here might help convince teachers that they already possess the strategies necessary for handling debates and discussions. Alternatively, if teachers actually feel unconfident about their own skills, this typology might serve as a guide in developing strategies to handle argumentative discourse. The fact that the typology also provides reasons causing teacher interventions might be very helpful in planning and preparing such activities.

There is some overlap between the strategies used in this study and the six generic strategies for conducting discussions proposed by Kelly (1989):

\section{Asking clear, focused questions \\ 2. Waiting for responses \\ 3. Calling on non-volunteers as well as volunteers \\ 4. Promoting student-student interaction \\ 5. Probing for clarity, definition and elaboration \\ 6. Checking to see whether one discussant understands another correctly}

Kelly further suggests that these strategies can transform typical classroom discussions from a rapid, ping-pong encounter between the teacher on the one side and a few isolated, highly vocal students on the other to a sustained, thoughtful, and coherent conversation among a broad range of peers. Several studies confirm Kelly's description of typical classroom discussions (e.g. Norrild et al., 2001; Haug, 2003) and the type of communicative approach that can be described as authoritative/dialogic.

The high frequency of authoritative/dialogic discourse reported in many science classrooms might be an obstacle for learning. Mortimer and Scott (2003) see talk as being central to the meaning making process and thus central to learning. They suggest that meaning making can be seen as a fundamentally dialogic process, where different ideas are brought together and worked upon i.e. an interactive/dialogic communicative approach. The discourse in the three present debates can be characterised as an interactive dialogic communication. The teacher and class are discussing and considering different viewpoints of a controversial issue. The students explore information related to the controversy and the teacher helps sustain the discussion both in terms of enabling students to contribute, and in challenging and asking for elaboration on points that are unclear. According to Scott (1998) the nature of teacher utterances in dialogic discourse is: framed to be open to challenge and debate, intended to act as "thinking devices" or "generators of meaning", often based on open or genuine questions where the answer is not obvious, directed towards sustaining dialogue and representing other voices. An interactive/dialogic communicative approach seems to be meaningful for practising argumentation in science classrooms and the strategies used by the teacher in this study seem to support this type of communicative approach.

In addition to lack of strategies for running group discussions, the teachers interviewed by Newton et al. (1999) pointed to advanced planning, time constraints and need of a prerequisite knowledge base as limiting factors regarding use of activities promoting argumentation. This study is an example overcoming these factors: When using existing digital teaching materials, i.e. the Viten wolf program, the planning of the teaching sequence was not more demanding than normal. In fact, one could rather say that using the wolf program shortened preparation time in terms of searching for information and planning activities since these components already were implemented in the program. Other teaching materials like textbooks, videos and CD-ROMs can also serve as basis for debates and discussions. 
Regarding time, students in this study spent in total six lessons on the whole teaching sequence, which could not be considered as time consuming. In fact, it might be recommended to practice small scale activities, instead of having too high ambitions. One could argue that the web-based Viten program made this teaching especially efficient regarding time spent. However, it is important to emphasize that only two lessons were spent preparing and performing debates.

From the empirical data six reasons causing teacher interventions are identified. These are all of a general character and might be recognized in other debates regardless of issue. The reasons might help teachers predict the processes of debates and discussions. As put forward by Dillon (1994), the unpredictable nature of discussions might be an important reason why teachers don't engage their students in such activities. Another factor that might influence the predictability of activities involving argumentation is to which extent they are guided by clear goals. Things happen quickly in debates, hence directing the activity towards clear goals might be helpful. Here, the stated goals acted as guidelines for the teacher in managing the debates and as the results show, they had a strong influence on when and how she intervened in the debates.

Using role-plays as TV-debates generates multiple opportunities for practicing argumentation and might also be a good vehicle for the teacher in practicing an interactive dialogic approach to classroom discourse. Running three short debates during one class period was effective in involving many students, both in the panel and audience. Kolstø (2000) observed that role-playing increased the possibility to understand other people's point of view when one had to place oneself in their situation. Here, observations were made that students usually not very interested in science really engaged in the work with the online part and the debate. Student engagement varied from passive observers, to those playing their roles fully and making special hats to emphasize their roles as hunters.

\section{Conclusions}

It has been suggested that teachers need guidance in how to approach activities engaging students in argumentation. The contribution of this study is a typology of teacher interventions and reasons causing them. Interventions and reasons are all of a general character and transferable to other debates regardless of issue. Hence, this typology has the potential to serve as a guiding tool for teachers when preparing and conducting debates and discussions.

The main reasons explaining infrequent use of activities involving argumentation in science lessons are that teachers lack strategies for handling debates and discussions, and that such activities are both time consuming and unpredictable. The strategies used by the teacher in this study are well known and probably part of most teachers' repertoire of teaching strategies. Furthermore, experiences from this study show that it is possible to run classroom debates without spending too much time, and by running several short debates during one class period many students can be involved. Practicing small scale activities is recommended.

As for the unpredictability of debates, the typology of teacher interventions and reasons causing them offers a helpful tool in preparing teachers for situations that might occur during the debates, and how to handle them. In addition, stating clear aims for the teaching sequence will make the purpose of the teaching clear for the students and act as a tool for the teacher in managing the debates.

\section{ACKNOWLEDGEMENTS}

This study is funded by a grant from the Norwegian Network for IT-Research and Competence in Education (ITU). I would especially like to thank John Leach and Jenny Lewis, University of Leeds, for comments on earlier drafts on the manuscript. I would also like to thank Doris Jorde, Wenche Erlien, Torunn Aanesland Strømme and the rest of the Viten team. 


\section{REFERENCES}

Costello, P. J. M., \& Mitchell, S. (1995). Introduction: Argument: Voices, text and contexts. In P. J. M. Costello \& S. Mitchell (Eds.), Competing and consensual voices. The theory and practice of argument. Clevedon and Adelaide: Multilingual Matters Ltd.

Dillon, J. T. (1994). Using discussions in classrooms. Buckingham: Open University Press.

Driver, R., Leach, J., Millar, R., \& Scott, P. (1996). Young people's images of science. Buckingham: Open University Press.

Driver, R., Newton, P., \& Osborne, J. (2000). Establishing the norms of scientific argumentation in classrooms. Science Education, 84(3), 287-312.

Duschl, R. A., \& Osborne, J. (2002). Supporting and promoting argumentation discourse in science education. Studies in Science Education, 38, 39-72.

Haug, P. (2003). Evaluering av Reform 97. Sluttrapport frå styret for Program for evaluering av Reform 97. Oslo: Norwegian Research Counsil.

Kelly, T. E. (1989). Leading class discussions of controversial issues. Social Education, October 1989, 368-370.

Kolstø, S. D. (2000). Consensus projects: Teaching science for citizenship. International Journal of Science Education, 22, 645-664.

Kolstø, S. D. (2001). "To trust or not to trust,..." -Pupil's ways of judging information encountered in a socio-scientific issue. International Journal of Science Education, 23(9), 877-901.

Kuhn, D. (1993). Science as argument: Implications for teaching and learning scientific thinking. Science Education, 77(3), 319-337.

Latour, B., \& Woolgar, S. (1986). Laboratory life. The construction of scientific facts. Princeton: Princeton University Press.

Millar, R., \& Osborne, J. (Eds.). (1998). Beyond 2000: Science education for the future. London: School of Education, Kings College.

Mork, S. M. (in prep.). A dual approach to analysing student argumentation in science lessons. Submitted to Science Education.

Mork, S. M., \& Jorde, D. (2003). Using information technology and controversy to promote discourse in science teaching. Paper presented at the The European Science Education Research Association conference 2003, Noordwijkerhout, The Netherlands.

Mork, S. M., \& Jorde, D. (2004). We know they love computers, but do they learn science? A study about the use of information technology and controversy in science instruction. Themes in Education, 5(1), 69-100.

Mortimer, E., \& Scott, P. (2003). Meaning making in secondary science classrooms. Maidenhead Philadelphia: Open University Press.

Newton, P., Driver, R., \& Osborne, J. (1999). The place of argument in the pedagogy of school science. International Journal of Science Education, 21(5), 553-576.

Norrild, P., Angell, C., Bang, H., Larsen, C., Paulsen, A., \& Stubgaard, S. (2001). Fysik i skolen - skolen i fysik. Evaluering af fysik $i$ det almene gymnasium. Copenhagen: Danmarks Evalueringsinstitut.

Ratcliffe, M. (1996). Adolescent desicion-making, by individual and groups, about science-related societal issues. In G. Welford, J. Osborne \& P. Scott (Eds.), Research in Science Education in Europe: Current Issues and Themes. London: Falmer.

Ratcliffe, M. (1997). Pupil decision-making about socio-scientific issues within the science curriculum. International Journal of Science Education, 19(2), 167-182.

Sadler, T. D. (2004). Informal reasoning regarding socioscientific issues; a critical rewiev of research. Journal of Research in Science Teaching, 41(5), 513-536.

Scott, P. (1998). Teacher talk and meaning making in science classrooms: a Vygotskyan analysis and review. Studies in Science Education, 32, 45-78.

Simonneaux, L. (2001). Role-play or debate to promote students' argumentation and justification on an issue in animal transgenesis. International Journal of Science Education, 23(9), 903927. 
Solomon, J. (1991). Group discussions in the classroom. School Science Review, 72, 29-34.

Solomon, J. (1992). The classroom discussion of science-based social issues presented on television: knowledge, attitudes and values. International Journal of Science Education, 14, 431444.

Wellington, J., \& Osborne, J. (2001). Language and literacy in science education. Buckingham, Philadelphia: Open University Press.

Zohar, A., \& Nemet, F. (2002). Fostering students' knowledge and argumentation skills through dilemmas in human genetics. International Journal of Research in Science Teaching, 39(1), 35-62. 